\title{
Investigating the effective factors on electronic trade by viral marketing
}

\author{
Nina Ghane ${ }^{a^{*}, \text { Hamid Reza Shokrizadeh }}{ }^{\mathrm{b}}$, Maryam Omidvar ${ }^{\mathrm{a}}$ and Hoseyn Comyab ${ }^{\mathrm{a}}$
}

${ }^{a}$ Master of Business Management, Ershad university, Tehran, Iran

${ }^{b}$ Department of Management, Payame Noor University, PO BOX 19395-3697, Tehran, Iran

CH R O I C L E A B T RACT

Article history:

Received July 28, 2013

Received in revised format

20 November 2013

Accepted 14 January 2014

Available online

February 172014

Keywords:

Virtual marketing

Internet

e-business

\section{Introduction}

During the past two decades, the information technology has introduced some new ideas and platforms for communications. As a powerful media, Internet has revolutionized the business in the world. One of the most important issues is that online communities interact without considering geographical boarders (Reich, 2010). It has raised some challenges in understanding this new environment and consumers' action within it (Ulmanen, 2011). According to Fetscherin and Lattemann (2008), internet users spend significant amount of time on the Internet to interact with others in order to communicate, to collaborate, or to cooperate through different channels and applications such as e-mail, online games, or instant messaging. There is a new idea of the "small world" where any pair of people in a vast, random network can actually connect with each other in a predictable way through relatively short paths of mutual acquaintance. Furthermore, each person is

*Corresponding author.

E-mail addresses: nina_ghane68@yahoo.com (N. Ghane)

This paper performs an investigation to explore a number of strategies underpinning virtual marketing. The study also provides several suggestions for marketers seeking to use viral marketing to position brands or to change a brand's image, to encourage new product trials and to increase product uptake rates. In this article, we investigate the effect of external factors such as capturing the imagination, targeting credible sources, leveraging combinations of technology and easy to use product on virtual marketing. In addition, the study considers internal factors such as inclusion (the need to be part of a group, the need to be different) and affection on viral marketing. The survey has been accomplished among 140 Iranian people, who were familiar
with virtual marketing and they are selected, randomly. Using Pearson correlation as well as regression analysis, the study provides some evidences that there were some positive and meaningful relationship between some internal/external factors and virtual marketing.

C 2014 Growing Science Ltd. All rights reserved. 
estimated to be directly connected with 300 others, we may show that 90000 people could be only two steps away from any given person. In addition, 27 million people are three steps away from other people. Based on the idea of "small world" concept, the demand for information, the good intention to share the experience or the ideas about the products and services, the capability of the customer-tocustomer $(\mathrm{C} 2 \mathrm{C})$ communications as the electronic peer-to-peer referrals on Internet and the potential for getting recommendations from mutual acquaintances have raised a considerable potential for Viral Marketing (VM) (Ridings et al., 2002). In addition, the effective mixture of the traditional idea called Word of Mouth (WOM) and the modern tools could be provided within the virtual environment (Chaffey et al., 2006). This is why Kurucz (2008) states that VM has the potential to become the most important issue of promotion and Chaffey et al. (2006) emphasized that it is increasingly being used for commercial purposes. Sormunen (2009) argued that viral marketing could become a new media phenomenon, attracting increasing interest in the marketing literature and it can be deployed based on various instruments and forms. Each form of VM could offer various perspectives for researchers for investigation. On the other hand, to design a viral marketing campaign, it is advisable to know both target consumers and their associates very well (Sormunen, 2009).

\section{Viral Marketing}

\subsection{Viral Marketing History}

In 1997, Steve Jurvetson used the term "viral marketing" as "network-enhanced word of mouth" and as an efficient method in reaching a large number of people rapidly as similar as a natural virus or a computer virus (Woerndl, 2008; Wiedemann et al., 2008; Sormunen, 2009; Xavier \& Summer, 2009; Eckler \& Rodgers, 2010). In recent years, many famous and big enterprises such as Nike, McDonalds (Testa, 2007), Microsoft, Philips, Sony, Ford, BMW (Wiedemann et al., 2008), Procter and Gamble, Toyota, and Burger King (Xavier \& Summer, 2009), have used viral contents. However, there are some evidences to believe that Fortune 500 firms were far less likely to engage in viral campaigns than non-Fortune 500 companies (Porter \& Golan, 2006). Kulp (2007) discussed the shortage of VM through an empirical investigation. In addition, there are few studies on different aspects of viral marketing such as consumer acceptance. Therefore, it is still in its infancy and calls for more academic researches (Kurucz, 2008; Xavier \& Summer, 2009; Sormunen, 2009). Furthermore, Wiedemann (2008) argued that although there were some evidences on the usefulness of VM from marketers' perspective, there is a little information about the motivations, attitudes, and behaviors of consumers engaged in this marketing instrument. Their focus was on Mobile VM.

\subsection{Viral Marketing Definition}

Being a relatively new concept, there are several different interpretations of VM (Kurucz, 2008). Kiss and Bichler (2008) defined VM as "marketing techniques that use social networks to produce increases in brand awareness through self-replicating viral diffusion of messages, analogous to the spread of pathological and computer viruses". Kim and Lowrey (2010) stated VM as "a marketing strategy or a marketing phenomenon that facilitates and encourages people to pass along a marketing message to other people".

VM can be considered to be the equivalent to "Online word-of-mouth", which refers to all informal communications associated with the usage or characteristics of specific goods and services or their sellers directed at consumers through Internet-based technology (Litvin et al., 2008). Sometimes it is referred to as "electronic word-of-mouth (e-WOM)" or more interesting "word-of-mouse" (Litvin et al., 2008; Ulmanen, 2011). Xavier and Summer (2009) explains VM as an electronic extension of word-of-mouth. Though the focus of this term is mainly on online interactions, Kurucz (2008) suggests that other traditional marketing techniques basing on the word-of-mouth effect should not 
been excluded because of its offline context. Some researchers have emphasized the nature of informal environment of VM (Porter \& Golan, 2006; Litvin et al., 2008; Woernd1, 2008). Eckler and Rodgers (2010) discuss the advantages of VM as the reduced cost of promotion, increased credibility, increased visibility, decreased interruption, and improved format flexibility. They discuss disadvantages as the reduced control of the marketer, increased reliance on consumers' motivation, and increased risk of negative reactions.

In summary, VM is a very specific type of communication that concerns word-of mouth behavior about a brand. Rosen (2001) describes VM as an aggregate person-to-person communication about a particular product, service, or company at any point in time, which leads to explosive self-generating demand (Dye, 2000). However, many studies detected word-of-mouth referrals and VM as marketing legend and confused it with other marketing tools such as public relationship, sponsorship and testimonial activities or linked with standard adoption and diffusion models. VM can also be defined as an individual forwarding an electronic mail message they receive to other people on their e-mail lists or tying an advertisement into or at the end of an electronic message. Unlike other forms of marketing, the viral message contains a form of advocacy or word-of-mouth referral endorsement from one client forwarding messages to prospective clients. The trick for marketers is to encourage existing, happy clients to pass on a message they considered enjoyable or compelling enough, either by designing the communication to fit these criteria or through accident, such that a user would voluntarily pass the message on to other users (Clow \& Baack, 2001). For example, the promoters of The Blair Witch Project did an excellent job of utilizing Internet word-of-mouth referrals or VM. To support the truthfulness claim, the movie's creators provided a website with evidence from the case including the sheriff's reports, photographs and details of the Blair Witch. Other supporting documentation included a comic book and, in the 12-month lead up to the movie's launch, chat sites were also incorporated.

\section{The effective factors on viral marketing}

\section{1 external factors}

\subsubsection{Capturing the imagination}

Fun is a vital part of any viral marketing campaign. The amount of noise in the market can make evaluation of the product difficult for the consumer.

\subsubsection{Visible, easy to use products}

Dye (2000) identified a number of perspectives of products most susceptible to the 'buzz' type phenomenon, including unique products, highly visible products and products that are naturally susceptible to word-of-mouth discussion.

\subsubsection{Targeting credible sources}

The influence, and in some cases the power, of reference groups or opinion leaders in the individual's decision-making process may be significant. Having the consumer by passing further external information searches means that any potential competitors are knocked out of the decision making process.

\subsubsection{Leveraging combinations of technology}

Incorporating traditional media with the new forms available to today's marketers also appears to be a winning strategy. Traditionally sponsorship has depended on the placement of the sponsor's logo on 
posters, tickets, T-shirts and signage at the venue. Although sponsorship may place the brand in the awareness set its affect provides little opportunity to move the consumer further down the decision making process.

\subsection{Internal factors}

\subsubsection{Inclusion}

The interpersonal need for inclusion is associated with the need to be recognized as participants in human interaction and some terms that connote the relation include "belong", "join", and "togetherness". However, an important feature of the concept of inclusion is the desire to be identifiable or different from others. This means to postulate two primary motives underlying the interpersonal need of inclusion the need to belong and the need to be unique.

\subsubsection{The need to be part of a group}

According to the belongingness hypothesis, human beings possess "a need to form and maintain at least a minimum quantity of interpersonal relationships" (Baumeister \& Leary, 1995:499). Phelps et al. (2004) examined consumers' motivations to pass along email and found that the most common motivation mentioned by respondents was the wish to connect and to share with others. Flanagin and Metzger (2001) studied individuals' motivations for applying a number of different media and reported that similar to interpersonal (face-to-face) communication, electronic mail was implemented heavily to fulfill social bonding and relationship maintenance requirements. As more people depend on the Internet as a way of communication we surmise that many young adults need to share their media experiences particularly if they anticipate future discussions.

\subsubsection{The need to be different}

Self-image motivates WOM communication, for instance, a recent study by Chung and Darke (2006) found that individuals were more likely to engage in WOM for products closely aligned to one's selfimage that is, products that tell others about who we are. This is not the only study to recommend that impression management objectives are important drivers of WOM communication. Sundaram et al. (1998) explored consumers' motivations to engage in WOM and reported that self-enhancement was an important motivator for engaging in positive WOM approximately 20 percent of their respondents had initiated WOM as a means of enhancing status. Cheung et al. (2008) reported that individuals could construct or assert their sense of self by using WOM to gain attention and connote status. Chen and Dhillon (2003) suggested that the motivation to see oneself as distinctive could be a pervasive

human motivation. Individuation is described as the willingness to stand out or be different from others and some studies have indicated that people who are high in public individuation are more willing to voice their opinions and stand out in a community (Maslach et al., 1985). Chan and Misra (1990) introduced the concept of individuation to the opinion leadership literature and proposed that the "act of disseminating information through word of- mouth communication makes opinion leaders stand out among their group, makes them "different" than the other members."

\subsubsection{Affection - the need to be altruistic}

Affection is defined as the need to maintain a satisfactory relationship, leading individuals to engage in behaviors related to intimacy, warmth and emotional involvement (Cheung et al., 2008). Since people driven by the need for affection desire relationships that are close and personal, we posit that this need is closely associated with the concept of altruism or concern for others (Price et al., 1995). We often consider altruistic acts as selfless, or in other words, actions based on love and affection. 
We explain that in the context of forwarding online content, altruistic motivations may be the most relevant indicator of the need for affection. For instance,

\section{The conceptual model of research}

This model derived from above literature, so we divided the effective factors on viral marketing in two groups, the external factors, which are associated with feature of websites and internal factors, which are associated with client of websites. We present the model of this research in Fig 1.

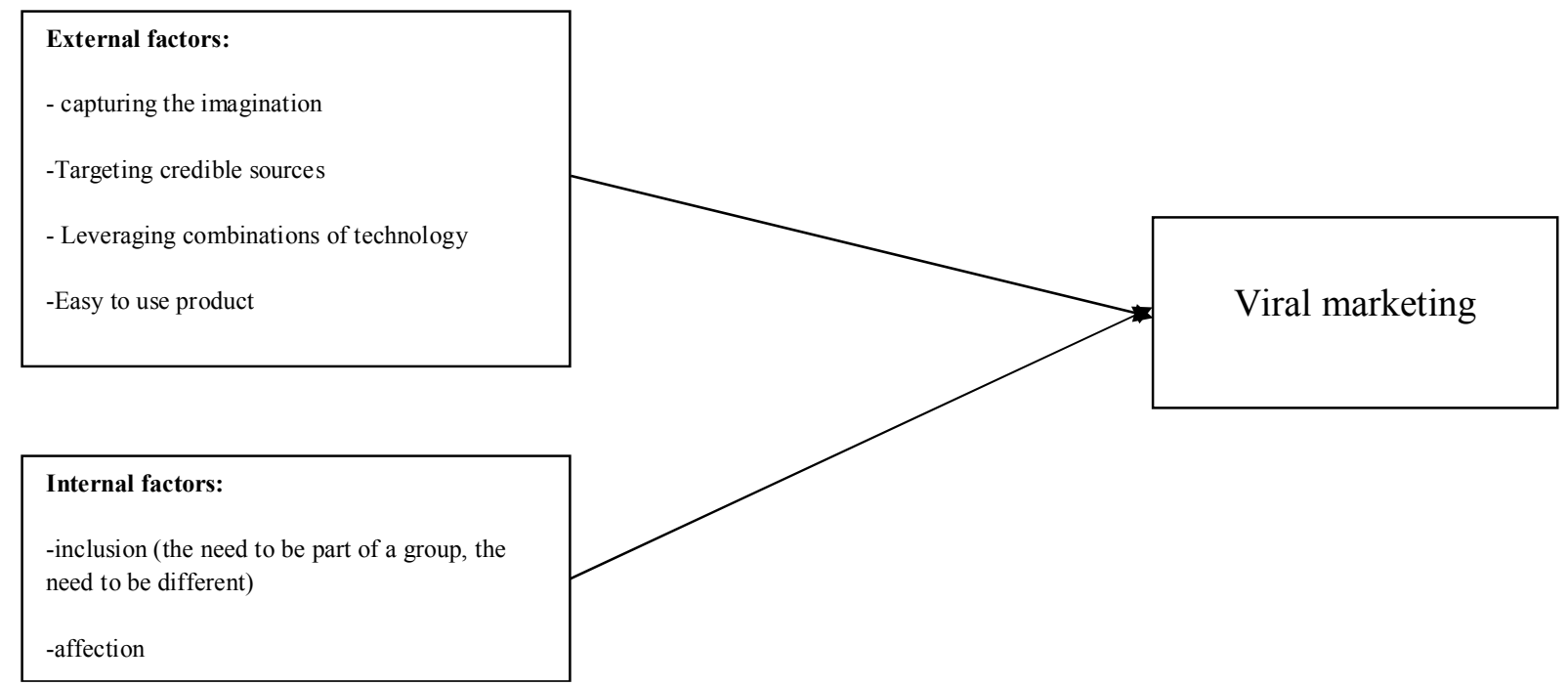

Fig. 1. The effective factors on viral marketing

\section{Research methodology}

This study is descriptive-survey research and in the following stage, we describe the effective factors associated with viral marketing on websites. For gathering data, we use five-item questionnaire in Likert scale. The reliability of the questionnaire is 0.886 in according to Cronbach alpha. In addition, Table 1 demonstrates Cronbach alpha for other variables.

\section{Table 1}

The components and Cronbach alpha

\begin{tabular}{llll}
\hline Variable & Cronbach alpha & Variable & Cronbach alpha \\
\hline affection & 0.70 & Easy to use product & 0.88 \\
Inclusion(need to be different) & 0.89 & Leveraging combination of technology & 0.743 \\
Inclusion(need to be part of a group) & 0.86 & Targeting credible source & 0.75 \\
Capturing the imagination & 0.82 & Viral marketing & 0.78 \\
\hline
\end{tabular}

\subsection{Research design and sample selection}

The statistical population of this study includes of websites and factories in various classes of multiple areas of Tehran. The sample size is determined as 140 clients, which is determined as follows,

$$
N=Z_{\alpha / 2}^{2} \frac{p \times q}{e^{2}},
$$


where $N$ is the sample size, $p=1-q$ represents the probability, $z_{\alpha / 2}$ is CDF of normal distribution and finally $\varepsilon$ is the error term. For our study we assume $p=0.5, z_{\alpha / 2}=1.96$ and $e=0.06$, the number of sample size is calculated as $N=98$. Table 2 shows details of the proposed study of this paper. The proposed study has computed Kolmogrov-Smirnov test to find out whether the data are normally distrbuted or not and the results have confirmed that all data are normally distributed. Table 2 shows details of our findings on the implementation of Pearson correlation data along with the components of the survey.

\section{Table 2}

The measure component of our variables

\begin{tabular}{|c|c|c|c|}
\hline Hypothesis & Research construct & Measure component & $\mathrm{r}$ \\
\hline $\mathrm{H}_{1}$ & Capturing the imagination & Fun, entertainment & 0.78 \\
\hline $\mathrm{H}_{2}$ & Targeting credible source & $\begin{array}{l}\text { power of reference groups or opinion leaders in the individual's } \\
\text { decision making, clients trust }\end{array}$ & 0.55 \\
\hline $\mathrm{H}_{3}$ & Leveraging combinations of technology & SMS promotion link, new and up to date technology & 0.83 \\
\hline $\mathrm{H}_{4}$ & Easy to use product & $\begin{array}{l}\text { unique products (e.g., collapsible scooters), highly visible products } \\
\text { (e.g., Gucci baguette bags and Palm Pilots) and products that are } \\
\text { naturally susceptible to word-of-mouth discussion (e.g., Viagra). }\end{array}$ & 0.75 \\
\hline $\mathrm{H}_{5}$ & Inclusion(the need to be in a group) & $\begin{array}{l}\text { a need to form and maintain at least a minimum quantity of } \\
\text { interpersonal relationships }\end{array}$ & 0.93 \\
\hline $\mathrm{H}_{6}$ & Inclusion( the need to be different) & Self-image motivates WOM communication. & 0.86 \\
\hline $\mathrm{H}_{7}$ & affection & $\begin{array}{l}\text { the need to maintain a satisfactory relationship, leading individuals } \\
\text { to engage in behaviors related to intimacy, warmth and emotional } \\
\text { involvement }\end{array}$ & 0.88 \\
\hline
\end{tabular}

As we can observe from the results of Table 2, there are positive and meaningful relationships between different components of the survey. In addition, Table 3 shows details of regression analysis.

Table 3

The result of our hypothesis

\begin{tabular}{llllllll}
\hline Hypotheses & Independent variables & Dependent variable & $\mathrm{R}$ & $\mathrm{R}^{2}$ & $\mathrm{~F}$ & Sig & result \\
\hline $\mathrm{H}_{1}$ & Capturing the imagination & Viral marketing & 0.631 & 0.398 & 81.394 & 0.000 & Accepted \\
$\mathrm{H}_{2}$ & credible source & Viral marketing & 0.744 & 0.553 & 152.092 & 0.000 & Accepted \\
$\mathrm{H}_{3}$ & Leveraging combinations of technology & Viral marketing & 0.436 & 0.190 & 28.804 & 0.000 & Accepted \\
$\mathrm{H}_{4}$ & Easy to use product & Viral marketing & 0.529 & 0.280 & 47.800 & 0.000 & Accepted \\
$\mathrm{H}_{5}$ & Inclusion(the need to be in a group) & Viral marketing & 0.178 & 0.032 & 4.046 & 0.046 & Rejected \\
\hline $\mathrm{H}_{6}$ & Inclusion( the need to be different) & Viral marketing & 0.432 & 0.186 & 41.700 & 0.000 & Rejected \\
$\mathrm{H}_{7}$ & affection & Viral marketing & 0.231 & 0.053 & 53.800 & 0.000 & Rejected \\
\hline
\end{tabular}

As mentioned before, based on a comprehensive survey of the literature, seven hypotheses were developed in this study. According to the statistical analysis of hypotheses examined the correlation between the variables in all of the hypotheses were confirmed. As we can observe, most important variables maintain meaningful effects on viral marketing. The effects of three variables such as inclusion (the need to be in a group and the need to be different) and affection on viral marketing were not confirmed.

\section{Discussion and conclusion}

The examples of viral marketing highlighted in this paper showed four common themes for success. Successful viral marketing campaigns had an underlying critical dependency on the consumer perceiving value within the viral transmission and deeming this value worthy of passing on to others. What is important is that the consumers never feel they are being used in passing branding and advertising messages to others. It is a tough line to work, but on the bright side - let's face it, people talk. The challenge for marketers is harnessing this natural will to talk through that almost tailor made tool, the Internet. It makes talking easier for customers and its low-cost, needs minimal 
response time and potential market effects make it attractive for businesses willing to put in the effort of thoughtful viral marketing design and campaign implementation. Managing and encouraging customers' word-of-keyboard (WOK) activities had interesting results for the cases discussed. The results indicate the importance, in general, of successful Web site design to system use. Customers rather than business organizations should control the on-line transaction process.

\section{References}

Baumeister, R. F., \& Leary, M. R. (1995). The need to belong: desire for interpersonal attachments as a fundamental human motivation. Psychological bulletin, 117(3), 497.

Chaffey, D., Ellis-Chadwick, F., Mayer, R., \& Johnston, K. (2006). Internet Marketing, Strategy, Implementation and Practice ( $3^{\mathrm{rd}}$ ed.). Pearson Education Limited.

Chen, S. C., \& Dhillon, G. S. (2003). Interpreting dimensions of consumer trust in e-commerce. International Journal of Human-Computer Studies, 4(2-3), 303-318.

Chan, K. K., \& Misra, S. (1990). Characteristics of the opinion leader: A new dimension. Journal of advertising, 19(3), 53-60.

Chung, C. M., \& Darke, P. R. (2006). The consumer as advocate: self-relevance, culture, and wordof-mouth. Marketing Letters, 17(4), 269-279.

Cheung, C., Lee, M., \& Rabjohn, N. (2008). The impact of electronic word-of-mouth: the adoption of online opinions in online customer communities. Internet Research, 18(3), 229-247.

Clow, K.E., \& Baack, D. (2001). Integrating Advertising, Promotion \& Marketing Communications. New Jersey, Prentice-Hall.

Dye, R. (2000). The buzz on buzz. Harvard Business Review, Nov-Dec, 139-146.

Eckler, P., \& Rodgers, S. (2010). Viral Marketing on the Internet. Wiley International Encyclopedia of Marketing. John Wiley \& Sons Ltd. http://dx.doi.org/10.1002/9781444316568

Flanagin, A. J., \& Metzger, M. J. (2001). Internet use in the contemporary media environment. Human communication research, 27(1), 153-181.

Fetscherin, M., \& Lattemann, C. (2008). User acceptance of virtual worlds. Journal of Electronic Commerce Research, 9(3), 213-242

Kiss, C., \& Bichler, M. (2008). Identification of influencers-measuring influence in customer networks. Decision Support Systems, 46(1), 233-253. http://dx.doi.org/10.1016/j.dss.2008.06.007 automation, department of communications and networking.

Keller Fay Group and Bazaar voice Study Finds Altruism Drives Online Reviews (November2007), http://www.kellerfay.com/pdf/BazaarVoice11-26-07.pdf, accessed December4, 2007.

Kulp, S. C. (2007). Advertising among ourselves: a qualitative study of viewer attitudes towards viral marketing.

Kurucz, V. (2008). Perspectives of viral marketing among managers: an Internet based assessment. Dissertation for the degree of MA. University of Lugano Faculties of Communication and Economics Sciences.

Litvin, S., Goldsmith, R., \& Pan, B. (2008). Electronic word-of-mouth in hospitality and tourism management.Tourism Management, 29(3), 458-468.

Maslach, C., Stapp, J., \& Santee, R. T. (1985). Individuation: Conceptual analysis and assessment. Journal of Personality and Social Psychology, 49(3), 729.

Palka, W., Pousttchi, K., \& Wiedemann, D. G. (2009). Mobile word-of-mouth - a grounded theory of mobile viral marketing. Journal of Information Technology, 24, 172-185. 
Phelps, J. E., Lewis, R., Mobilio, L., Perry, D., \& Raman, N. (2004). Viral marketing or electronic word of mouth: examining consumer responses to pass-along email. Journal of Advertising Research, 44(12), 333-348.

Porter, L., \& Golan, G. (2006). From subservient chickens to brawny men: A comparison of viral advertising to television advertising. Journal of Interactive Advertising, 6(2), 30-38.

Phelps, J. E., Lewis, R., Mobilio, L., Perry, D., \& Raman, N. (2004). Viral marketing or electronic word-of-mouth advertising: Examining consumer responses and motivations to pass along email. Journal of Advertising Research, 44(4), 333-348.

Porter, L., \& Golan, G. J. (2006). From subservient chickens to brawny men: A comparison of viral advertising to television advertising. Journal of Interactive Advertising, 6(2), 30-38.

Phelps, J. E., Lewis, R., Mobilio, L., Perry, D., \& Raman, N. (2004). Viral marketing or electronic word-of-mouth advertising: Examining consumer responses and motivations to pass along email. Journal of advertising research,44(4), 333-348.

Price, L. L., Feick, L. F., \& Guskey, A. (1995). Everyday Market Helping Behavior. Journal of Public Policy \& Marketing, 14(2). 255-66.

Reich, S. (2010). Adolescents' sense of community on MySpace and Facebook: a mixed methods approach. Journal of Community Psychology, 38(6), 688-705.

Ridings, C. M., Gefe D., \& Arinze, B. (2002). Some antecedents and effects of trust in virtual communities. Journal of Strategic Information Systems, 11(3-4), 271-295.

Rosen, E. (2001). The anatomy of Buzz: creating word-of-mouth marketing, London, Harper Collins Publishers.

Schutz, W.C. (1966). FIRO: A Three Dimensional Theory of Interpersonal Behavior. New York: Holt, Rinehart, \& Winston.

Sundaram, D. S., Mitra, K., \& Webster, C. (1998). Word-of-Mouth Communications: A Motivational Analysis. Advances in consumer research,25(1). 527-531

Sormunen, V. (2009). International viral marketing campaign planning and evaluation. Dissertation for the Degree of MA, Department of Marketing and Management, Helsingin KAauppakorkeakoulu, Helsinki School of Economics.

Testa, D. L. (2007). Mining the language of online discussions in the service of mass market communications. A dissertation presented in partial fulfillment of the requirements for the degree Doctor of Philosophy, Capella University.

Toleman, D. (2004). Lured but not caught? How A.I. set the bait, in C. Neal, Quester, and D. Hawkins, Consumer Behaviour, McGraw Hill, Australia.

Ulmanen, H. (2011). Antecedents of and their effect on trust in online word-of-mouth: case Finnish discussion forums, Dissertation for the Degree of MA, marketing university of Jyvaskyla, school of Business and Economics.

Wiedemann, D. G., Palka, W., \& Pousttchi, K. (2008). Understanding the determinants of mobile viral effects-towards a grounded theory of mobile viral marketing. mobile business, ICMB '08. 7th International Conference on, 323-333.

Woerndl, M. (2008). Internet-induced marketing techniques: critical factors in viral marketing campaigns. International Journal of Business Science and Applied Management, 3(1), 33-45.

Xavier, L. J. W., \& Summer, G. Y. S. (2009). Viral marketing communication: the Internet word-ofmouth, a study on consumer perception and consumer response. Dissertation for the Degree of MA in Business 